\title{
Pengaruh Proporsi Tepung Terigu dan Tepung Ampas Tahu terhadap Kandungan Protein dan Serat serta Daya Terima Biskuit Program Makanan Tambahan Anak Sekolah (PMT-AS)
}

\author{
Nany Suryani ${ }^{1}$, Christina Mumpuni Erawati ${ }^{2}$, Shella Amelia ${ }^{3}$ \\ ${ }_{1,2,3}$ Program Studi Gizi, STIKES Husada Borneo \\ J1. A. Yani Km 30,5 No.4 Banjarbaru, Kalimantan Selatan \\ Email: nan_cdy@yahoo.co.id
}

\begin{abstract}
ABSTRAK
Ampas tahu merupakan limbah dalam bentuk padatan dari bubur kedelai yang masih memiliki kandungan protein yang sangat tinggi dan banyak mengandung serat serta mudah diperoleh. Hal tersebut dapat dikembangkan menjadi suatu bentuk produk biskuit sebagai makanan tambahan anak sekolah (PMT-AS). Tujuan dari penelitian ini adalah menganalisis pengaruh proporsi tepung terigu dan tepung ampas tahu dengan kandungan protein dan serat serta daya terima pada biskuit. Penelitian ini menggunakan Rancangan Acak Lengkap (RAL) dengan 4 perlakuan dan 3 kali replikasi dengan masing - masing perlakuan yaitu P0 (100 : 0), P1 (65 : 35), P2 (60 : 40), P3 (55 : 45). Metode pengujian kadar protein dengan metode Kjehdal dan serat dengan metode gravimetri. Metode pengujian organoleptik dengan metode Hedonic Scale Scoring. Analisis statistik yang digunakan untuk daya terima adalah uji Friedman sedangkan untuk kadar protein dan serat menggunakan analisis One Way ANOVA. Hasil penelitian didapatkan berpengaruh tidak nyata antara proporsi tepung terigu dan tepung ampas tahu terhadap kadar protein biskuit $(\mathrm{p}=0.168)$. Berpengaruh secara nyata antara proporsi tepung terigu dan tepung ampas tahu dengan kadar serat biskuit $(\mathrm{p}=0.000)$. Berpengaruh secara nyata antara proporsi tepung terigu dan tepung ampas tahu dengan daya terima warna, aroma, tekstur biskuit $(\mathrm{p}=0.002),(\mathrm{p}=0.003)$ dan $(\mathrm{p}=0.007)$. Berpengaruh tidak nyata antara proporsi tepung terigu dan tepung ampas tahu dengan daya terima rasa biskuit $(\mathrm{p}=0.377)$. Perlakuan terbaik dari segi kadar protein adalah perlakuan P2 dengan nilai rata-rata $10.3 \%$ perlakuan terbaik dari segi kadar serat adalah perlakuan P2 dengan nilai rata-rata $3.53 \%$. dan perlakuan terbaik tingkat kesukaan dengan skor suka pada (warna,aroma,tekstur,rasa) adalah perlakuan P2.
\end{abstract}

Kata Kunci: pengaruh proporsi tepung terigu, ampas tahu, protein, serat daya terima biskuit

\section{The Effect of the Proportion of Wheat Flour and Tofu Grout Flour to Protein and Fiber Ingredients and Biscuit Power Received Program Food Supplement Children School (PMT- AS)}

\begin{abstract}
Dregs tofu is a waste in the form of a slurry of soy solids which still has a very high protein content and fiber and it easily obtained. It can be developed into a form of alternative nutritional biscuits as a food supplementary school aged children. The purpose of this study was to determine the effect of wheat flour and dregs tofu flour with its protein and fiber content also
\end{abstract}


acceptability of the biscuits. This study uses a completely randomized design with 4 treatments and 3 times replication with each treatment that is P0 (100: 0), P1 (65: 35), P2 (60: 40), P3 (55: 45). Methods of testing for protein content by the method Kjehdal and fiber by gravimetric method. Organoleptic testing method with Hedonic Scoring Scale. Statistical test organoleptic using Friedman test. Statistical test levels of protein and fiber using One Way ANOVA. The result showed no influence between the proportion of wheat flour and dregs tofu flour to the protein content of the biscuit $(\mathrm{p}=0.168)$. There is influence between the proportion of wheat flour and dregs tofu flour with a fiber content of biscuits $(p=0.000)$. There is influence between the proportion of flour and dregs tofu with the acceptability of color, aroma, texture biscuits $(\mathrm{p}=$ $0.002),(p=0.003)$ and $(p=0.007)$. There is no effect between the proportion of wheat flour and dregs tofu flour with biscuit of flavor acceptability $(p=0.377)$. The best treatment in terms of protein content is the treatment of P2 with an average value of $10.3 \%$ in terms of the best treatment is the treatment of the fiber content of P2 with the average value of 3:53\% and the best treatment preference level with a score like the (color, aroma, texture, taste) is treatment P2.

Keywords: influence of proportion of wheat flour, the dregs of tofu, protein, fiber power received biscuits

\section{Pendahuluan}

Perkembangan status gizi di Indonesia yang belum selesai dikendalikan yaitu gizi kurang. ${ }^{1}$ Kekurangan energi protein adalah salah satu masalah gizi kurang akibat konsumsi makanan yang tidak cukup mengandung energi dan protein serta gangguan kesehatan ${ }^{2}$. Berdasarkan data Riskesdas, prevalensi status gizi kurang pada anak-anak umur 6-12 tahun cukup tinggi yaitu sebanyak $63.1 \%$, dimana $8.2 \%$ gizi buruk dan 19.2\% gizi kurang ${ }^{3}$. Pemberian makanan tambahan terhadap anak juga perlu mempertimbangkan angka kecukupan gizi berdasarkan usia anak 7-9 tahun yaitu energi 1850 kal, Protein 49 g, lemak 72 g, karbohidrat $254 \mathrm{~g}$, serat $26 \mathrm{~g}$. Anak laki-laki usia 10-12 tahun kebutuhan energi $2100 \mathrm{kal}$, protein $56 \mathrm{~g}$, lemak $70 \mathrm{~g}$, karbohidrat $289 \mathrm{~g}$, serat 30 g. Sedangkan anak perempuan 10-12 tahun kebutuhan energi $2000 \mathrm{kal}$, protein $60 \mathrm{~g}$, lemak $67 \mathrm{~g}$, karbohidrat $275 \mathrm{~g}$, serat $28 \mathrm{~g}$, serat $30 \mathrm{gr}^{4}$.
Berbagai jenis makanan yang dapat dijadikan sebagai PMT-AS adalah bubur kacang hijau, dan berbagai jenis biskuit ${ }^{5}$. Tepung merupakan bahan utama dalam pembuatan biskuit.Tepung yang umum digunakan dalam pembuatan biskuit adalah tepung terigu yang memiliki kandungan protein sebesar $8-9 \%{ }^{6}$. Sementara itu, ampas tahu merupakan limbah dalam bentuk padatan dari bubur kedelai yang diperas dan tidak berguna lagi dalam pembuatan tahu dan cukup potensial dipakai sebagai bahan makanan karena ampas tahu masih mengandung gizi yang baik ${ }^{7}$. Berdasarkan uraian diatas penulis tertarik untuk melakukan penelitian pengaruh proporsi tepung terigu dan tepung ampas tahu dengan kandungan protein, serat dan daya terima pada biskuit sebagai makanan alternatif program makanan tambahan (PMT-AS).

\section{Metode Penelitian}

Jenis penelitian ini bersifat eksperimen dengan Rancangan penelitian 
Nany Suryani, Christina Mumpuni Erawati, Shella Amelia, Pengaruh Proporsi Tepung Terigu dan Tepung Ampas Tahu terhadap Kandungan Protein dan Serat serta Daya Terima Biskuit Program Makanan Tambahan Anak Sekolah (PMT-AS)

DOI : $10.24853 / j k k \cdot 14 \cdot 1.11-25$

yang digunakan adalah rancangan acak lengkap (RAL) dengan 4 perlakuan dan 3 kali pengulangan. Teknik pengumpulan data meliputi data hasil uji protein, serat dan organoleptik. Uji ini menggunakan kuesioner yang digunakan untuk mengetahui tingkat kesukaan panelis yang terdiri dari empat kriteria: Skor $4=$ Sangat suka, $3=$ Suka, $2=$ Kurang suka, 1 = Tidak suka. Kandungan protein dianalisis dengan menggunakan ANOVA dan uji Tukey. Sedangkan untuk daya terima dianalisis dengan menggunakan uji Friedman.

\section{Hasil}

Kandungan Protein dan Serat Tepung

\section{Ampas Tahu dan Tepung Terigu}

Berdasarkan Tabel 1, kandungan protein dan serat pada tepung ampas tahu lebih besar dibandingkan dengan pada tepung terigu.

Tabel 1. Rata-Rata Kandungan Protein dan Serat Tepung Ampas Tahu dan Tepung Terigu

\begin{tabular}{|c|c|c|}
\hline \multirow{2}{*}{ Jenis Tepung } & \multicolumn{2}{|c|}{ Nilai Rata-Rata (\%) } \\
\hline & Protein & Serat \\
\hline Tepung Ampas Tahu & 21.53 & 12.13 \\
\hline Tepung Terigu & 8.05 & 3.49 \\
\hline
\end{tabular}

\section{Kandungan Protein Biskuit}

Tabel 2 menunjukkan bahwa nilai rata-rata kandungan protein biskuit yang tertinggi pada P3 yaitu sebesar 11.78\%. Sedangkan nilai rata-rata kandungan protein terendah pada P0 yaitu sebesar 9.15\%. Berdasarkan analisis statistik ANOVA menunjukkan nilai $\mathrm{p}=0.168 \quad(\mathrm{p}>0.05)$ yang artinya tidak ada pengaruh antara proporsi tepung terigu dan tepung ampas tahu dengan kandungan protein biskuit.

Nilai rata-rata kandungan serat biskuit yang tertinggi pada P3 yaitu sebesar $4.91 \%$. Sedangkan nilai rata-rata kandungan serat terendah pada P0 yaitu sebesar $1.58 \%$. Berdasarkan analisis statistik ANOVA menunjukkan nilai $\mathrm{p}=0,000 \quad(\mathrm{p}<0.05)$ yang artinya ada pengaruh proporsi tepung terigu dan tepung ampas tahu dengan kandungan protein biskuit. Hal ini berarti akan dilanjutkan dengan uji perbandingan ganda (tukey), untuk melihat kombinasi perlakuan yang berbeda. Berdasarkan analisis tukey menunjukkan bahwa perlakuan yang berbeda secara nyata P0 dengan P2 $(\mathrm{p}=0.000)$, P0 dengan P3 $(\mathrm{p}=0.000), \quad \mathrm{P} 1$ dengan P2 $(\mathrm{p}=0.005), \mathrm{P} 2$ dengan $\mathrm{P} 3$ ( $\mathrm{p}=0.002)$.

Tabel 2. Rata-Rata Kandungan Protein Biskuit Perlakuan (Tepung Terigu : Nilai Rata-rata Nilai RataTepung Ampas Protein (\%) rata serat

\begin{tabular}{ccc} 
Tahu & & $(\boldsymbol{\%})$ \\
\hline $\mathrm{P} 0(100: 0)$ & 9.15 & 1.58 \\
\hline $\mathrm{P} 1(65: 35)$ & 9.97 & 2.32 \\
\hline $\mathrm{P} 2(60: 40)$ & 10.3 & 3.53 \\
\hline $\mathrm{P} 3(55: 45)$ & 11.78 & 4.91 \\
\hline
\end{tabular}

\section{Daya Terima Warna}

Tabel 3. Rata-Rata Daya Terima Warna Biskuit

\begin{tabular}{ccc}
\hline $\begin{array}{c}\text { Perlakuan } \\
\text { (Tepung Terigu : } \\
\text { Tepung Ampas } \\
\text { Tahu) }\end{array}$ & $\begin{array}{c}\text { Rata-rata } \\
\text { Daya Terima } \\
\text { Warna }\end{array}$ & Keterangan \\
\hline P0 (100:0) & 3.28 & Suka \\
\hline P1 (65:35) & 3.16 & Suka \\
\hline P2 (60:40) & 3.04 & Suka \\
\hline P3 (55:45) & 2.56 & Kurang Suka \\
\hline
\end{tabular}

Uji Friedman $\mathrm{p}=0.002$ 
Tabel 3 menunjukkan bahwa daya terima panelis terhadap warna biskuityang tertinggi adalah pada perlakuan P0 dengan nilai rata-rata 3.28. Sedangkan yang terendah adalah pada perlakuan P3 dengan nilai ratarata 2.56. Hasil uji statistik Friedman menunjukkan nilai $\mathrm{p}=0.002(\mathrm{p}<0.05)$.

\section{Daya Terima Aroma Biskuit}

Tabel 4 menunjukkan bahwa daya terima panelis terhadap aroma biscuit yang tertinggi adalah pada perlakuan P0 dengan nilai rata-rata 3.28. Sedangkan yang terendah adalah pada perlakuan P3 dengan nilai ratarata 2.56. Hasil uji statistik Friedman menunjukkan nilai $\mathrm{p}=0.003(\mathrm{p}<0.05)$. Artinya berpengaruh secara nyata antara proporsi tepung terigu dan tepung ampas tahu dengan daya terima aroma biskuit.

Tabel 4. Rata-Rata Daya Terima Aroma

Biskuit

\begin{tabular}{ccc}
\hline $\begin{array}{c}\text { Perlakuan } \\
\text { (Tepung Terigu : } \\
\text { Tepung Ampas } \\
\text { Tahu) }\end{array}$ & $\begin{array}{c}\text { Rata-rata } \\
\text { Daya Terima } \\
\text { Aroma }\end{array}$ & Keterangan \\
\hline P0 (100:0) & 3.28 & Suka \\
\hline P1 (65:35) & 3.08 & Suka \\
\hline P2 (60:40) & 3.20 & Suka \\
\hline P3 (55:45) & 2.56 & Kurang Suka \\
\hline Uji Friedman $\mathrm{p}=0,003$ &
\end{tabular}

\section{Daya Terima Tekstur Biskuit}

Tabel 5 menunjukkan bahwa daya terima panelis terhadap tekstur biskuit yang tertinggi adalah pada perlakuan P2 dengan nilai rata-rata 3.32. Sedangkan yang terendah adalah pada perlakuan P3 dengan nilai ratarata 2.60. Hasil uji statistik Friedman

menunjukkan nilai $\mathrm{p}=0.007(\mathrm{p}<0.05)$, artinya berpengaruh secara nyata antara proporsi tepung terigu dan tepung ampas tahu dengan daya terima tekstur biskuit.

Tabel 5. Rata-rata Daya Terima Tekstur Biskuit

\begin{tabular}{ccc}
\hline $\begin{array}{c}\text { Perlakuan } \\
\text { (Tepung Terigu } \\
\text { : Tepung } \\
\text { Ampas Tahu) }\end{array}$ & $\begin{array}{c}\text { Rata-rata } \\
\text { Daya } \\
\text { Terima } \\
\text { Tekstur }\end{array}$ & Keterangan \\
\hline P0 $(100: 0)$ & 3.12 & Suka \\
\hline P1 $(65: 35)$ & 3.24 & Suka \\
\hline P2 $(60: 40)$ & 3.32 & Suka \\
\hline P3 (55:45) & 2.60 & Kurang Suka \\
\hline
\end{tabular}

Uji Friedman $\mathrm{p}=0.007$

\section{Daya Terima Rasa Biskuit}

Tabel 6 menunjukkan bahwa daya terima panelis terhadap rasa biscuit yang tertinggi adalah pada perlakuan P2 dengan nilai rata-rata 3.20. Sedangkan yang terendah adalah pada perlakuan P1 dengan nilai ratarata 3. Hasil uji statistik Friedman menunjukkan nilai $\mathrm{p}=0.377(\mathrm{p}>0.05)$. Artinya berpengaruh secara nyata antara proporsi tepung terigu dan tepung ampas tahu dengan daya terima rasa biskuit.

\section{Tabel 6. Rata-Rata Daya Terima Rasa Biskuit} Perlakuan

(Tepung Terigu Rata-rata : Tepung Daya Ampas Tahu) Terima Rasa

\begin{tabular}{lll}
\hline P0 $(100: 0)$ & 3.12 & Suka \\
\hline P1 $(65: 35)$ & 3.00 & Suka \\
\hline P2 $(60: 40)$ & 3.20 & Suka \\
\hline P3 $(55: 45)$ & 3.04 & Suka \\
\hline Uji Friedman $\mathrm{p}=0.377$ & &
\end{tabular}


Nany Suryani, Christina Mumpuni Erawati, Shella Amelia, Pengaruh Proporsi Tepung Terigu dan Tepung Ampas Tahu terhadap Kandungan Protein dan Serat serta Daya Terima Biskuit Program Makanan Tambahan Anak Sekolah (PMT-AS)

DOI : $10.24853 / j k k \cdot 14 \cdot 1.11-25$

\section{Pembahasan}

Kadar Protein Tepung Ampas Tahu dan Tepung Terigu

Hasil penelitian menunjukkan bahwa dalam 100 gram tepung ampas tahu mengandung $21.53 \%$ protein dan berdasarkan Tabel 1 hasil penelitian menunjukkan bahwa dalam 100 gram tepung terigu mengandung $8.05 \%$ protein.

Kadar protein ampas tahu mempunyai nilai biologis lebih tinggi dari pada protein biji kedelai dalam keadaan mentah, karena bahan ini berasal dari kedelai yang telah dimasak. Kandungan senyawa pada ampas tahu yang cukup berpotensi adalah sebagai sumber antioksidan alami ${ }^{8}$. Hasil pengeringan ampas tahu dapat diolah menjadi produk tepung ampas tahu yang bisa memenuhi kandungan gizi lebih tinggi dan fleksibel dalam penggunaannya. Menurut Syafitri ${ }^{9}$, pengaruh tepung ampas tahu mampu meningkatkan kandungan protein makanan yang dihasilkan seiring dengan meningkatnya penambahan tepung ampas tahu terhadap produk yang dihasilkan.

Berdasarkan Tabel 1 hasil penelitian menunjukkan bahwa dalam 100 gram tepung ampas tahu mengandung $21.53 \%$ protein dan dalam 100 gram tepung terigu mengandung $8.05 \%$ protein. Ampas tahu mempunyai nilai biologis lebih tinggi dari pada protein biji kedelai dalam keadaan mentah, karena bahan ini berasal dari kedelai yang telah dimasak ${ }^{8}$. Kandungan senyawa pada ampas tahu yang cukup berpotensi adalah sebagai sumber antioksidan alami. Hasil pengeringan ampas tahu dapat diolah menjadi produk tepung ampas tahu yang bisa memenuhi kandungan gizi lebih tinggi dan fleksibel dalam penggunaannya. Pengaruh tepung ampas tahu mampu meningkatkan kandungan protein makanan yang dihasilkan seiring dengan meningkatnya penambahan tepung ampas tahu terhadap produk yang dihasilkan ${ }^{9}$.

\section{Kadar Serat Tepung Ampas Tahu dan Tepung Terigu}

Hasil penelitian menunjukkan bahwa dalam 100 gram tepung ampas tahu mengandung $12.13 \%$ serat dan berdasarkan Tabel 1 hasil penelitian menunjukkan bahwa dalam 100 gr tepung terigu mengandung $3.49 \%$ serat. Suhu pada perendaman berpengaruh terhadap kandungan serat ${ }^{10}$.

Kandungan nutrisi yang terdapat dalam ampas tahu bervariasi, hal ini antara lain disebabkan oleh perbedaan varietas dari kedelai yang digunakan sebagai bahan dasar pembuatan tahu, peralatan yang digunakan dalam proses pembuatan tahu maupun proses pembuatan ampas tahu pada pengolahan yang dilakukkan ${ }^{11}$. Serat merupakan salah satu komponen yang sering digunakan dalam komposisi diet sehari-hari. Serat memiliki fungsi mencegah terjadinya beberapa penyakit yang berhubungan dengan saluran pencernaan, kardiovaskuler dan diabetes ${ }^{12}$.

Berdasarkan Tabel 1 hasil penelitian menunjukkan bahwa dalam 100 gram tepung ampas tahu mengandung $12.13 \%$ serat dan 
dalam 100 gr tepung terigu mengandung $3.49 \%$ serat. Ampas tahu dalam bentuk tepung kaya akan komponen serat/oligosakarida. Selain itu, dalam pembuatan tahu terjadi proses pemanasan dengan suhu $100^{\circ} \mathrm{C}$, waktu 15 menit. Hal tersebut mempengaruhi kandungan serat pada ampas tahu, suhu pada perendaman berpengaruh terhadap kandungan serat $^{10}$. Kandungan nutrisi yang terdapat dalam ampas tahu bervariasi, hal ini antara lain disebabkan oleh perbedaan varietas dari kedelai yang digunakan sebagai bahan dasar pembuatan tahu, peralatan yang digunakan dalam proses pembuatan tahu maupun proses pembuatan ampas tahu pada pengolahan yang dilakukkan ${ }^{11}$.

\section{Kadar Protein Biskuit}

Kadar protein tertinggi adalah biscuit pada perlakuan ke empat (P3) dengan proporsi tepung terigu 55 gr dan tepung ampas tahu 45 gr yaitu sebesar $11.78 \%$. Sedangkan kadar protein paling rendah adalah biskuitpada perlakuan kontrol (P0) dengan proporsi tepung terigu $100 \mathrm{gr}$ dan tepung ampas tahu 0 gr yaitu sebesar $9.15 \%$.

Kadar protein ampas tahu mempunyai nilai biologis lebih tinggi dari pada protein biji kedelai dalam keadaan mentah, karena bahan ini berasal dari kedelai yang telah dimasak ${ }^{8}$. Kandungan senyawa pada ampas tahu yang cukup berpotensi adalah sebagai sumber antioksidan alami.Hasil pengeringan ampas tahu dapat diolah menjadi produk tepung ampas tahu yang bisa memenuhi kandungan gizi lebih tinggi dan fleksibel dalam penggunaannya.

Protein merupakan suatu zat gizi yang amat penting bagi tubuh, karena zat ini disamping berfungsi sebagai bahan bakar dalam tubuh juga berfungsi sebagai zat pembangun dan pengatur ${ }^{7}$. Selain itu protein adalah sumber asam-asam amino yang mengandung unsur $\mathrm{C}, \mathrm{H}, \mathrm{O}$ dan $\mathrm{N}$ yang tidak dimiliki oleh lemak atau karbohidrat. Molekul protein juga mengandung pula fosfor dan belerang, selain itu ada jenis protein yang mengandung unsur logam seperti besi dan tembaga ${ }^{13}$.

Protein adalah bagian dari semua sel hidup dan merupakan bagian terbesar tubuh sesudah air. Semua enzim, berbagai hormon, pengangkut zat-zat gizi dan darah, matriks intraseluler dan sebagainya adalah protein. Protein mempunyai fungsi khas yang tidak dapat tergantikan oleh zat gizi lain, yaitu membangun serta memelihara sel-sel dan jaringan tubuh. Protein dalam bahan makanan yang dikonsumsi manusia akan diserap oleh usus dalam bentuk asam amino ${ }^{14}$.

Tabel 2 menunjukkan bahwa kadar protein tertinggi adalah biskuit pada perlakuan ke empat (P3) dengan proporsi tepung terigu 55 gr dan tepung ampas tahu 45 gr yaitu sebesar $11.78 \%$. Sedangkan kadar protein paling rendah adalah biskuit pada perlakuan kontrol (P0) dengan proporsi tepung terigu 100 gr dan tepung ampas tahu 0 gr yaitu sebesar $9.15 \%$. Berdasarkan analisis statistik ANOVA menunjukkan nilai $\mathrm{p}=0.168(\mathrm{p}>0.05)$ 
Nany Suryani, Christina Mumpuni Erawati, Shella Amelia, Pengaruh Proporsi Tepung Terigu dan Tepung Ampas Tahu terhadap Kandungan Protein dan Serat serta Daya Terima Biskuit Program Makanan Tambahan Anak Sekolah (PMT-AS)

DOI : $10.24853 / j k k \cdot 14 \cdot 1.11-25$

yang artinya tidak ada pengaruh proporsi tepung terigu dan tepung ampas tahu terhadap kadar protein biskuit.

Walaupun tidak berpengaruh secara statistik, namun berdasarkan Tabel 2 dapat dilihat bahwa kadar protein biskuit dari ke empat perlakuan mengalami peningkatan seiring dengan bertambahnya proporsi tepung ampas tahu. Hal ini dikarenakan kandungan protein pada tepung ampas tahu lebih banyak dibandingkan kadar protein pada tepung terigu. Berdasarkan Tabel 1 dalam 100 gr tepung ampas tahu mengandung protein sebanyak 21.53 gr Kadar protein. Sedangkan dalam 100 gr tepung terigu dengan jenis kadar protein rendah mengandung 8.05 gr protein.

Protein ampas tahu mempunyai nilai biologis lebih tinggi dari pada protein biji kedelai dalam keadaan mentah, karena bahan ini berasal dari kedelai yang telah dimasak ${ }^{8}$. Kandungan senyawa pada ampas tahu yang cukup berpotensi adalah sebagai sumber antioksidan alami. Hasil pengeringan ampas tahu dapat diolah menjadi produk tepung ampas tahu yang bisa memenuhi kandungan gizi lebih tinggi dan fleksibel dalam penggunaannya. Bahan pembuatan biskuit terdiri dari tepung terigu, susu skim, telur, gula, garam, shortening dan bahan pengembang. Dari semua bahan penyusunnya, ada beberapa bahan yang kaya akan protein diantaranya adalah tepung terigu, susu skim, dan telur.

Kadar protein biskuit dipengaruhi oleh adanya proses pemanasan yang akan mengakibatkan berkurangnya kadar protein. Kebanyakan protein dalam pangan terdenaturasi jika dipanaskan pada suhu moderat $\left(60-90^{\circ} \mathrm{C}\right)$ selama satu jam atau kurang. Denaturasi adalah perubahan struktur protein dimana pada keadaan terdenaturasi penuh, hanya struktur primer protein saja yang tersisa, protein tidak lagi memiliki struktur sekunder, tersier dan quarterner. Akan tetapi, belum terjadi pemutusan ikatan peptida pada kondisi terdenaturasi penuh ini. Denaturasi protein yang berlebihan dapat menyebabkan insolubilisasi yang dapat mempengaruhi sifatsifat fungsional protein dan tergantung pada kelarutannya.

Berkurangnya kadar protein selama proses pemanasan juga diakibatkan oleh reaksi Maillard. Reaksi Maillard merupakan reaksi antar gula pereduksi dengan protein pada suhu $150-260^{\circ} \mathrm{C}$ yang menyebabkan warna coklat pada makanan. Pada reaksi ini, asam-asam amino terutama lisin berikatan dengan glukosa dan fruktosa membentuk produk akhir melanoidin, protein termodifikasi dan senyawa aromatik seperti trimetil pirazin, tetrametil pirazin, benzaldehida, fenil asetaldehida dan senyawa lainnya yang merupakan sumber aroma yang khas pada produk reaksi Maillard dan bersifat volatile sehingga dapat menguap dan menyebabkan penurunan kadar protein pada makanan $^{15}$.

Mengacu pada Standar Nasional Indonesia (SNI) tahun 1992 tentang syarat mutu biskuit, batas minimum kadar protein 
pada biskuit yaitu 9\%. Hasil penelitian menunjukkan dari semua perlakuan dapat dikatakan sudah mencapai standar SNI tahun 1992. Yaitu lebih dari 9\%. Dengan kadar protein tertinggi pada P3 $(55: 45)$ sebesar $11.78 \%$.

Biskuit dapat dijadikan salah satu alternatif makanan selingan yang praktis dan sehat. Oleh karena itu perlu diciptakan suatu produk biskuit mempunyai nilai gizi tinggi yang dapat digunakan untuk makanan tambahan anak sekolah. Menurut AKG (2013) kebutuhan protein untuk anak usia 7-9 tahun adalah 49 gr, dan untuk anak usia 10-12 tahun adalah 56 gr (laki-laki) dan 60 gr (perempuan). Perlakuan P3 mengandung kadar protein tertinggi yaitu $11.78 \%$ (11.78 gram per 100 gram biskuit / \pm 10 keping biskuit) sehingga dapat menyumbang kebutuhan serat untuk anak usia 7-9 tahun sebesar 26 gr, untuk anak usia 10-12 tahun (laki-laki) sebesar 30 gram dan untuk anak usia 10-12 tahun (perempuan) sebesar 28 gr. Dampak pelaksanaan PMT-AS bagi peserta didik usia sekolah dasar diharapkan dapat memberi pengaruh positif terhadap ketahanan fisik anak. Ketahanan belajar siswa pada jam pelajaran di sekolah dan pada akhirnya dapat mempengaruhi prestasi belajar anak di sekolah (Tim Koordinasi PMT-AS Pusat, 2010).

\section{Kadar Serat Biskuit}

Kadar serat tertinggi adalah biskuit pada perlakuan ke empat (P3) dengan proporsi tepung terigu 55 gr dan tepung ampas tahu 45 gr yaitu sebesar $4.91 \%$. Sedangkan kadar serat paling rendah adalah biskuit pada perlakuan kontrol (P0) dengan proporsi tepung terigu 100 gr dan tepung ampas tahu 0 gr yaitu sebesar $1.58 \%$.

Menurut Hartono ${ }^{16}$ suatu produk pengolahan makanan yang dicampur dengan sumber nabati yang memiliki kandungan serat kasar dan dalam pencampuran bahan sempurna dapat meningkatkan kadar serat pada suatu produk yang dihasilkan. Serat merupakan salah satu komponen yang sering digunakan dalam komposisi diet sehari-hari. Serat memiliki fungsi mencegah terjadinya beberapa penyakit yang berhubungan dengan saluran pencernaan, kardiovaskuler dan diabetes ${ }^{16}$.

Tabel 2 menunjukkan bahwa kadar serat tertinggi adalah biskuit pada perlakuan ke empat (P3) dengan proporsi tepung terigu 55 gr dan tepung ampas tahu 45 gr yaitu sebesar $4.91 \%$. Sedangkan kadar serat paling rendah adalah biskuit pada perlakuan kontrol (P0) dengan proporsi tepung terigu 100 gr dan tepung ampas tahu 0 gr yaitu sebesar $1.58 \%$. Berdasarkan analisis statistik ANOVA menunjukkan nilai $\mathrm{p}=0.000 \quad(\mathrm{p}<0.05)$ yang artinya ada pengaruh proporsi tepung terigu dan tepung ampas tahu terhadap kadar serat biskuit.

Kadar serat biskuit dari keempat perlakuan mengalami peningkatan seiring dengan bertambahnya proporsi tepung ampas tahu. Hal ini dikarenakan kadar serat pada 
Nany Suryani, Christina Mumpuni Erawati, Shella Amelia, Pengaruh Proporsi Tepung Terigu dan Tepung Ampas Tahu terhadap Kandungan Protein dan Serat serta Daya Terima Biskuit Program Makanan Tambahan Anak Sekolah (PMT-AS)

DOI : $10.24853 / \mathrm{jkk} \cdot 14.1 .11-25$

tepung ampas tahu lebih banyak dibandingkan kadar serat pada tepung terigu. Produk pengolahan makanan yang dicampur dengan sumber nabati yang memiliki kandungan serat kasar dan dalam pencampuran bahan sempurna dapat meningkatkan kadar serat pada suatu produk yang dihasilkan ${ }^{16}$. Berdasarkan Tabel 1 Kadar serat dalam 100 gr tepung ampas tahu sebanyak 12.13 gr dan dalam 100 gr tepung terigu mengandung serat sebanyak 3.49 gr.

Hal ini menunjukkan semakin tinggi penambahan tepung ampas tahu maka akan tinggi pula kadar serat yang dihasilkan. Oleh karena itu kadar serat pada perlakuan P3 dengan proporsi tepung terigu dan tepung ampas tahu (55 gr : $45 \mathrm{gr}$ ) yaitu sebesar $4.91 \%$ paling tinggi dibandingkan dengan perlakuan kontrol atau penambahan tepung ampas tahu lainnya. Menurut AKG (2013) kebutuhan serat untuk anak usia 7-9 tahun sebesar 26 gr, untuk anak usia 10-12 tahun (laki-laki) sebesar 30 gram dan untuk anak usia 10-12 tahun (perempuan) sebesar 28 gr. Perlakuan P3 mengandung kadar serat 4.91\% (4.91 gram per 100 gram biskuit / \pm 10 keping biskuit). Sehingga dari 100 gr biskuit yang dihasilkan dari penelitian ini mampu mendukung asupan serat sebesar $4.91 \%$. Untuk memenuhi kebutuhan serat pada anak-anak dapat dilakukan juga dengan cara memfortifikasi serat ke dalam makanan yang sering dikonsumsi oleh sebagian besar anak-anak seperti biskuit.

\section{Daya Terima Warna Biskuit}

Secara umum daya terima warna biskuityang disukai oleh panelis yaitu pada perlakuan pertama (P0) dengan proporsi tepung terigu $100 \mathrm{gr}$ dan tepung ampas tahu 0 gr. Sedangkan daya terima warna biskuityang tidak disukai pada perlakuan ke empat (P3) dengan proporsi tepung terigu 55 gr dan tepung ampas tahu $45 \mathrm{gr}$.

\section{Menurut Apriantono ${ }^{17}$, kacang-} kacangan memiliki warna coklat dari pigmen dan akan berpengaruh terhadap warna produk dan juga aroma jika terjadi penambahan kacang-kacangan tersebut. Di antara sifat-sifat produk pangan yang paling menarik perhatian konsumen dan paling cepat pula memberikan kesan disukai atau tidak adalah sifat warna. Warna mempunyai arti dan peranan penting pada komoditas bahan pangan dan hasil pertanian lainnya. Peranan ini sangat nyata pada 3 hal, yaitu: daya tarik, tanda pengenal, dan atribut mutu. Daya tarik suatu makanan sangat berpengaruh oleh penampilan fisik dan warnanya. Hal ini merupakan salah satu faktor fisik yang menentukan dan menggugah selera orang untuk memilih makanan dan berpeluang besar untuk dibeli konsumen.

Warna merupakan komponen yang sangat penting dalam menentukan kualitas atau derajat penerimaan dari suatu bahan pangan. Suatu bahan pangan yang dinilai enak dan teksturnya baik tidak akan dimakan apabila memiliki warna yang kurang sedap dipandang atau telah menyimpang dari warna yang seharusnya. Penentuan mutu suatu bahan 
pangan tergantung dari beberapa faktor, tetapi sebelum faktor lain diperhatikan secara visual faktor warna tampil lebih dulu untuk menentukan mutu bahan pangan ${ }^{7}$. Selain sebagai faktor yang ikut menentukan mutu, warna juga dapat digunakan sebagai indikator kesegaran atau kematangan. Baik tidaknya cara pencampuran atau cara pengolahan dapat ditandai dengan adanya warna yang seragam dan merata.

Berdasarkan analisa statistik didapatkan nilai $\mathrm{p}=0.002(\mathrm{p}<0.05)$ artinya, ada pengaruh proporsi tepung terigu dan tepung ampas tahu terhadap daya terima warna biskuit. Secara umum daya terima warna biskuit yang disukai oleh panelis yaitu pada perlakuan pertama (P0) dengan proporsi tepung terigu $100 \mathrm{gr}$ dan tepung ampas tahu 0 gr. Sedangkan daya terima warna biskuit yang tidak disukai pada perlakuan ke empat (P3) dengan proporsi tepung terigu 55 gr dan tepung ampas tahu $45 \mathrm{gr}$. Hal ini dikarenakan semakin banyak penambahan tepung ampas tahu warna biskuit yang dihasilkan semakin coklat pekat. Sehingga panelis kurang menyukai biskuit pada perlakuan ke empat (P3). Panelis lebih menyukai warna biskuit yang agak terang yaitu P0, karena warna biskuit lebih terang dibandingkan perlakuan lainnya. Sedangkan P0 berwarna kuning terang, P2 kuning kecoklatan, dan pada perlakuan P3 berwarna coklat pekat. Warna biskuit sangat dipengaruhi oleh bahan dasar adonan.
Tepung ampas tahu berwarna putih kecoklatan dan aroma langu khas ampas tahu. Warna coklat gelap yang dikandung dalam tepung ampas tahu berasal dari pigmen kedelai, sehingga dihasilkan warna bahan baku yang gelap juga. Menurut Apriantono, kacang-kacangan memiliki warna coklat dari pigmen dan akan berpengaruh terhadap warna produk dan juga aroma jika terjadi penambahan kacang-kacangan tersebut ${ }^{17}$. Lesitin merupakan emulsifier dari ekstrak kedelai. Secara fisik, warna yang terdapat pada lesitin adalah coklat gelap. Ketika lesitin bertambah konsentrasinya, maka warna tersebut juga akan memberikan pengaruh terhadap warna fisik produk pangan, khususnya pada produk bakery.

Hasil penelitian juga menunjukkan adanya kecenderungan penurunan tingkat warna kuning seiring dengan penambahan lesitin. Hal ini karena warna dari lesitin, yaitu coklat gelap, yang ditambahkan pada biskuit memberikan pengaruh, yaitu biskuit menjadi lebih menurun tingkat kekuningannya.

\section{Daya Terima Aroma Biskuit}

Secara umum daya terima aroma biskuit yang disukai oleh panelis yaitu pada perlakuan pertama (P0) dengan proporsi tepung terigu $100 \mathrm{gr}$ dan tepung ampas tahu 0 gr. Sedangkan daya terima aroma biskuityang tidak disukai pada perlakuan ke empat (P3) dengan proporsi tepung terigu $55 \mathrm{gr}$ dan tepung ampas tahu 45 gr. Hal ini dikarenakan 
Nany Suryani, Christina Mumpuni Erawati, Shella Amelia, Pengaruh Proporsi Tepung Terigu dan Tepung Ampas Tahu terhadap Kandungan Protein dan Serat serta Daya Terima Biskuit Program Makanan Tambahan Anak Sekolah (PMT-AS)

DOI : $10.24853 / \mathrm{jkk} \cdot 14.1 .11-25$

ampas tahu memiliki aroma khas yaitu bau langu.

Aroma dari suatu produk terdeteksi ketika zat yang mudah menguap (volatile) dari produk tersebut terhirup dan diterima oleh sistem penciuman. Bau langu yang ditimbulkan oleh kerja enzim lipoksigenase yang ada dalam biji kedelai. Enzim tersebut bereaksi dengan lemak dan menghasilkan suatu senyawa organik yaitu etil-fenil-keton ${ }^{18}$.

Aroma makanan banyak menentukan kelezatan makanan tersebut, oleh karena itu aroma merupakan salah satu faktor dalam penentuan mutu ${ }^{7}$. Pada umumnya bau yang diterima oleh hidung dan otak lebih banyak merupakan ramuan atau campuran empat bau utama yaitu harum, asam, tengik dan hangus. Aroma makanan menentukan kelezatan bahan pangan tersebut. Dalam hal ini aroma lebih banyak sangkut pautnya dengan alat panca indera pencium. Aroma yang khas dan menarik dapat membuat makanan lebih disukai oleh konsumen sehingga perlu diperhatikan dalam pengolahan suatu bahan makanan.

Berdasarkan analisa statistik didapatkan nilai $\mathrm{p}=0.002(\mathrm{p}<0.05)$ artinya, ada pengaruh proporsi tepung terigu dan tepung ampas tahu terhadap daya terima aroma biskuit. Secara umum daya terima aroma biskuit yang disukai oleh panelis yaitu pada perlakuan pertama (P0) dengan proporsi tepung terigu $100 \mathrm{gr}$ dan tepung ampas tahu 0 gr. Sedangkan daya terima aroma biskuit yang tidak disukai pada perlakuan ke empat
(P3) dengan proporsi tepung terigu 55 gr dan tepung ampas tahu 45 gr. Hal ini dikarenakan ampas tahu memiliki aroma khas yaitu bau langu.

Aroma dari suatu produk terdeteksi ketika zat yang mudah menguap (volatile) dari produk tersebut terhirup dan diterima oleh sistem penciuman. Bau langu yang ditimbulkan oleh kerja enzim lipoksigenase yang ada dalam biji kedelai. Enzim tersebut bereaksi dengan lemak dan menghasilkan suatu senyawa organik yaitu etil-fenil-keton ${ }^{18}$. Aroma biskuit ditentukan oleh komponen bahan yang digunakan dan perbandingannya, seperti margarine, telur, bahan tambahan dan jenis tepung yang digunakan. Menurut Winarno, uji aroma lebih banyak melibatkan indera penciuman, karena kelezatan suatu makanan sangat ditentukan oleh aroma makanan tersebut dan merupakan salah satu indikator penting dalam menentukan kualitas bahan pangan ${ }^{7}$.

\section{Daya Terima Tekstur Biskuit}

Secara umum daya terima tekstur biskuityang disukai oleh panelis yaitu pada perlakuan ke tiga (P2) dengan proporsi tepung terigu 60 gr dan tepung ampas tahu $40 \mathrm{gr}$. Sedangkan daya terima tekstur biskuityang tidak disukai pada perlakuan ke empat (P3) dengan proporsi tepung terigu 55 gr dan tepung ampas tahu 45 gr. Karena menghasilkan adonan biskuityang lebih encer dibandingkan dengan perlakuan yang lain. 
Hal ini sesuai dengan pendapat Handayani dalam Turisyawati, yang menyatakan bahwa komponen utama yang terdapat dalam tepung yang berpengaruh terhadap tekstur adalah protein. Protein yang terdapat dalam terigu akan dapat membentuk gluten bila ditambah air, dengan adanya gluten dapat menyebabkan adonan bersifat elastis dan mampu menahan gas, sehingga pori-pori yang terbentuk dalam adonan juga kecil-kecil $^{19}$.

Tekstur atau konsistensi makanan juga merupakan komponen yang turut menentukan cita rasa makanan karena sensitivitas indera cita rasa dipengaruhi oleh konsistensi makanan. Makanan yang berkonsistensi padat atau kental akan memberikan rangsang yang lebih lambat terhadap indera kita. Konsistensi makanan juga mempengaruhi penampilan makanan yang dihidangkan. Ada banyak tekstur makanan antara lain halus atau tidak, cair atau padat, keras atau lembut, kering atau lembab.

Tekstur merupakan salah satu faktor penentu kualitas biskuit yang perlu diperhatikan, karena sangat berhubungan dengan derajat penerimaan konsumen. Pada umumnya biskuit yang dianggap baik adalah biskuit yang mempunyai tekstur mudah patah (brittle), yaitu jika biskuit ditekan dengan jari akan mudah patah ${ }^{19}$.

Berdasarkan analisa statistik didapatkan nilai $\mathrm{p}=0.018(\mathrm{p}<0.05)$ artinya, ada pengaruh proporsi tepung terigu dan tepung ampas tahu terhadap daya terima tekstur biskuit. Secara umum daya terima tekstur biskuit yang disukai oleh panelis yaitu pada perlakuan ke tiga (P2) dengan proporsi tepung terigu 60 gr dan tepung ampas tahu 40 gr. Sedangkan daya terima tekstur biskuit yang tidak disukai pada perlakuan ke empat (P3) dengan proporsi tepung terigu 55 gr dan tepung ampas tahu 45 gr. Karena menghasilkan adonan biskuit yang lebih encer dibandingkan dengan perlakuan yang lain.

Hal ini juga dipengaruhi oleh tingginya kadar air lebih banyak yaitu $10.5 \%$ sehingga biskuit yang dihasilkan tidak serenyah perlakuan yang lainnya. Hal ini dikarenakan tepung ampas tahu tidak mengandung gluten. Gluten pada adonan biskuit hanya berasal dari tepung terigu. Gluten terbentuk karena adanya pencampuran protein gliadin dan glutein yang terdapat pada tepung terigu pada saat pengadukan adonan. Jika gluten dicampur dengan air, maka volumenya akan membesar. Hal ini sesuai dengan pendapat Handayani dalam Turisyawati, yang menyatakan bahwa komponen utama yang terdapat dalam tepung yang berpengaruh terhadap tekstur adalah protein. Protein yang terdapat dalam terigu akan dapat membentuk gluten bila ditambah air, dengan adanya gluten dapat menyebabkan adonan bersifat elastis dan mampu menahan gas, sehingga pori-pori yang terbentuk dalam adonan juga kecil-kecil ${ }^{19}$. Akibatnya adonan tidak mengembang dengan baik, maka setelah pembakaran selesai akan menghasilkan produk yang keras. Selain kandungan protein 
Nany Suryani, Christina Mumpuni Erawati, Shella Amelia, Pengaruh Proporsi Tepung Terigu dan Tepung Ampas Tahu terhadap Kandungan Protein dan Serat serta Daya Terima Biskuit Program Makanan Tambahan Anak Sekolah (PMT-AS)

DOI : $10.24853 / j k k \cdot 14 \cdot 1.11-25$

pada tepung terigu, tekstur biskuit juga dipengaruhi oleh kandungan pati. Adanya air di dalam adonan akan menyebabkan pati mengalami penyerapan air, sehingga granula pati akan menggelembunng. Apabila dalam keadaan tersebut dipanaskan, pati akan tergelatinisasi, gel pati akan mengalami proses dehidrasi sehingga akhirnya gel membentuk kerangka yang kokoh, menyebabkan tekstur yang dihasilkan menjadi keras.

\section{Daya Terima Rasa Biskuit}

Secara umum daya terima rasa biskuityang disukai oleh panelis yaitu pada perlakuan ke tiga $(\mathrm{P} 2)$ dengan proporsi tepung terigu 60 gr dan tepung ampas tahu 40 gr. Sedangkan daya terima rasa biskuityang tidak disukai pada perlakuan kedua (P1) dengan proporsi tepung terigu $65 \mathrm{gr}$ dan tepung ampas tahu 35 gr.

Hal ini dikarenakan penambahan konsentrasi tepung ampas tahu dan yang rendah, sehingga rasa pahit yang berasal dari tepung ampas tahu. Selain itu proses pemasakan juga mempengaruhi rasa biskuit, seperti adanya proses karamelisasi yaitu adanya reaksi gula dengan protein yang berperan dalam penentuan warna hasil produksi yang dapat mengakibatkan browning.

Rasa merupakan faktor kedua yang menentukan cita rasa makanan setelah penampilan makanan itu sendiri. Apabila penampilan makanan yang disajikan merangsang saraf melalui indera penglihatan sehingga mampu membangkitkan selera untuk mencicipi makanan itu, maka pada tahap berikutnya cita rasa makanan itu akan ditentukan oleh rangsangan terhadap indera pencium dan indera pengecap ${ }^{20}$. Rasa lebih banyak melibatkan panca indera lidah. Bahan makanan yang mempunyai sifat merangsang syaraf perasa akan menimbulkan perasaan tertentu. Tekstur atau konsistensi suatu bahan akan mempengaruhi cita rasa yang ditimbulkan oleh bahan tersebut ${ }^{7}$.

$$
\text { Berdasarkan analisa statistik }
$$

didapatkan nilai $\mathrm{p}=0.377$ ( $\mathrm{p}>0.05)$ artinya, tidak ada pengaruh proporsi tepung terigu dan tepung ampas tahu terhadap daya terima rasa biskuit. Secara umum daya terima rasa biskuit yang disukai oleh panelis yaitu pada perlakuan ke tiga (P2) dengan proporsi tepung terigu 60 gr dan tepung ampas tahu 40 gr. Sedangkan daya terima rasa biskuit yang tidak disukai pada perlakuan kedua (P1) dengan proporsi tepung terigu $65 \mathrm{gr}$ dan tepung ampas tahu 35 gr.

Hal ini dikarenakan penambahan konsentrasi tepung ampas tahu dan yang rendah, sehingga rasa pahit yang berasal dari tepung ampas tahu. Selain itu proses pemasakan juga mempengaruhi rasa biskuit, seperti adanya proses karamelisasi yaitu adanya reaksi gula dengan protein yang berperan dalam penentuan warna hasil produksi yang dapat mengakibatkan browning. 


\section{Kesimpulan dan Saran}

Berdasarkan hasil penelitian ini maka dapat diambil kesimpulan sebagai berikut:

1. Rata-rata kadar protein dan serat pada tepung ampas tahu secara berurutan adalah $21.53 \%$ dan $12.13 \%$, sedangkan rata-rata kadar protein dan serat pada tepung terigu secara berurutan adalah $8,05 \%$ dan $3,49 \%$.

2. Rata-rata kadar protein pada biskuitP0 (9.15\%), P1 (9.97\%), P2 (10.3\%), P3 $(11.78 \%)$.

3. Rata-rata kadar serat pada biskuit P0 (1.58\%), P1 (2.32\%), P2 (3.53\%), P3 $(4.91 \%)$.

4. Tidak ada pengaruh proporsi tepung terigu dan tepung ampas tahu dengan kadar protein ( $\mathrm{p}>0.05)$.

5. Ada pengaruh proporsi tepung terigu dan tepung ampas tahu dengan kadar serat $(\mathrm{p}<0.05)$.

6. Ada pengaruh proporsi tepung terigu dan tepung ampas tahu dengan daya terima warna, aroma, dan tekstur $(\mathrm{p}<0.05)$.

7. Tidak ada pengaruh proporsi tepung terigu dan tepung ampas tahu dengan daya terima rasa $(\mathrm{p}>0.05)$.

8. Rata-rata daya terima tertinggi yang lebih disukai panelis yaitu P0 dan P2.

Biskuit pada perlakuan ke tiga (P2) dapat dimanfaatkan untuk makanan alternative program pemberian makanan tambahan anak sekolah (PMT-AS) karena sudah memenuhi syarat SNI biscuit dengan nilai gizi protein $10,3 \%$ dan serat $3,53 \%$.
Dapat dilakukan penelitian lebih lanjut untuk mengetahui kandungan zat gizi lain seperti karbohidrat, lemak maupun zat gizi mikro yang ada dalam biscuit.

\section{Daftar Pustaka}

1. Kementerian Kesehatan. Profil Kesehatan Indonesia Tahun 2012. Kementerian Kesehatan RI. 2013. 507 $\mathrm{p}$

2. Soekirman. Widyakarya Nasional Pangan dan Gizi (WNPG) VIII Jakarta. Jakarta: Lembaga Ilmu Pengetahuan Indonesia; 2004.

3. Badan Penelitian dan Pengembangan Kesehatan Republik Indonesia. Riset Kesehatan Dasar (RISKESDAS) 2013. Badan Penelitian dan Pengembangan Kesehatan Kementerian Kesehatan RI. 2013.

4. Kementerian Kesehatan Republik Indonesia. Permenkes No. 75 tahun 2013 tentang AKG 2013. Jakarta: Kementerian Kesehatan Republik Indonesia; 2013. p. 10.

5. Sari KTP. Pemanfaatan Tepung Biji Nangka (Artocarpus heterophyllus lamk) sebagai Substitusi dalam Pembuatan Kudapan Berbahan Dasar Tepung Terigu untuk PMT pada Balita. Universitas Negeri Semarang; 2012.

6. Departemen Kesehatan Republik Indonesia. Daftar Komposisi Zat Gizi Pangan Indonesia. Indonesia: Niaga 
Nany Suryani, Christina Mumpuni Erawati, Shella Amelia, Pengaruh Proporsi Tepung Terigu dan Tepung Ampas Tahu terhadap Kandungan Protein dan Serat serta Daya Terima Biskuit Program Makanan Tambahan Anak Sekolah (PMT-AS)

DOI : $10.24853 / j k k \cdot 14 \cdot 1.11-25$

Swadaya; 1995.

7. Winarno FG. Kimia Pangan dan Gizi. Jakarta: Gramedia Pustaka Utama; 2004.

8. Prabowo A, Samaih, Rangkuti. Pemanfaatan Ampas Tahu sebagai Makanan Tambahan Dalam Usaha Penggemukan Domba Potong. In: Proceeding Seminar. Bandung: Lembaga Kimia Nasional - LIPI; 1993.

9. Syafitri D. Pengaruh Substitusi Tepung Ampas Tahu pada Kue Ulat Sutra terhadap Kualitas Organoleptik dan Kandungan Gizi. Universitas Negeri Semarang; 2009.

10. Herawati R, Jamarun N. Pengaruh Suhu dan Lama Perendaman terhadap Kandungan Bahan Kering, Protein Kasar, Serat Kasar, dan HCN Biji Karet (Hevea brasiliensis). J Penelit Andalas. 2001;35.

11. Wahyuni S. Karakteristik Nutrisi Ampas Tahu yang Dikeringkan sebagai Pakan Domba. Universitas Diponegoro; 2003.

12. Abdillah F. Penambahan Tepung Wortel dan Karagenan untuk Meningkatkan Kadar Serat Pangan pada Nugget Ikan Nila (Oreochromis sp). Institut Pertanian Bogor; 2006.

13. Budianto AK. Dasar-Dasar Ilmu Gizi. Malang: UMM Press; 2009.

14. Almatsier S. Prinsip Dasar Ilmu Gizi. Jakarta: Gramedia Pustaka Utama; 2009.
15. Muchtadi D. Teknik Evaluasi Nilai Gizi Protein. Bandung: Alfabeta; 2010.

16. Purwono, Hartono R. Bertanam Jagung Unggul. Jakarta: Penebar Swadaya; 2007.

17. Apriantono A. Titik Kritis Kehalalan Bahan Pembuat Produk Bakery dan Kue [Internet]. 2009. Available from: http://dapurhalal.com/artikel-46-Titik-

Kritis-Kehalalan-Bahan-PembuatProduk-Bakery-\&-Kue---Part-I.html

18. Rahmawati H, Rustanti N. Pengaruh Substitusi Tepung Tempe dan Ikan Teri Nasi (Stolephorus sp.) terhadap Kandungan Protein, Kalsium, dan Organoleptik Cookies. J Nutr Coll. 2014;2(3):382-90.

19. Turisyawati R. Pemanfaatan Tepung Suweg (Amorphopallus campanulatus) sebagai Subtitusi Tepung Terigu pada Pembuatan Cookies. Universitas Sebelas Maret Surakarta; 2011.

20. Hakim UN, Rosyidi D, Widati AS. Pengaruh Penambahan Tepung Garut (Maranta arrundinaceae) terhadap Kualitas Fisik dan Organoleptik Nugget Kelinci. 2005;8(2):9-22. 